\title{
Analysis Of Behavior And Sosio-Economic Impact Of Relocation Of Street Vendors During The Covid-19 Pandemic
}

\author{
Sinta Putri Janah ${ }^{1}$, Hendri Hermawan Adinugraha ${ }^{2}$ \\ E-mail : sintapj69@gmail.com \\ IAIN Pekalongan \\ Jl.Pahlawan KM 5, Kajen, Kab. Pekalongan
}

\begin{abstract}
Abstrak
Pedagang kaki lima merupakan alternatif usaha di sektor informal dengan modal yang relatif kecil untuk menunjang kebutuhannya. Dalam memenuhi kebutuhan sehari-hari, kita pasti membutuhkan pemasukan atau pemasukan. Oleh karena itu, kita membutuhkan pekerjaan yang dapat menunjang kebutuhan kita. Tujuan penelitian ini adalah mendeskripsikan perilaku PKL dalam perspektif etika bisnis Islam dan mendeskripsikan kondisi sosial ekonomi relokasi PKL sebelum dan sesudah pandemi Covid-19. Desain penelitian yang digunakan adalah deskriptif diskusi. Pengumpulan data dilakukan dengan menggunakan metode wawancara mendalam, observasi, dan dokumentasi. Data dianalisis menggunakan metode kualitatif. Hasil penelitian menunjukkan bahwa perilaku PKL sesuai dengan etika bisnis Islam. Dampak kondisi sosial ekonomi pedagang kaki lima akhir-akhir ini banyak mengalami perubahan akibat diterapkannya relokasi. Pendapatan para pedagang rata-rata menurun, terutama sejak pandemi Covid-19, itupun sebagian dari mereka sudah berganti profesi.
\end{abstract}

Kata Kunci : Dampak, Sosial Ekonomi, Relokasi, Pedagang Kaki Lima

\begin{abstract}
Street vendors are an alternative to businesses in the informal sector with relatively small capital to support their needs. In meeting our daily needs, we definitely need income or income. therefore, we need a job which is to support our needs. The purpose of this study is to describe the behavior of street vendors in the perspective of Islamic business ethics and to describe the socio-economic conditions of relocation of street vendors before and after the Covid-19 pandemic. The research design used is descriptive discussion. Data were collected by using in-depth interviews, observation, and documentation methods. Data were analyzed using qualitative methods. The results of the study show that the behavior of street vendors is in accordance with Islamic business ethics. The impact of the socio-economic conditions of street vendors has recently undergone many changes due to the implementation of relocation. The income of traders has decreased on average, especially since the Covid-19 pandemic, and even then some of them have changed their profession.
\end{abstract}

Keywords: Socio-economic impact, Relocation, Street Vendors

\section{Introduction}

Economic growth that continues to increase accompanied by the phenomenon of globalization of trade and investment which causes the increasing need for skilled workers to support work affects the level of the community's economy, namely in terms of the limitations of job providers. The phenomenon of economic dualism that 


\section{Analysis Of Behavior And Sosio-Economic Impact Of Relocation \\ Of Street Vendors During The Covid-19 Pandemic \\ Sinta Putri Janah dan Hendri Hermawan Adinugraha}

gave birth to the informal sector shows evidence of the separation between the formal and informal sectors of a national economy. This has resulted in a very high increase in unemployment and a large socio-economic inequality (Mulyadi, 2003).

The informal sector according to the ILO (International Labor Organization) is a sector that is easy for entrepreneurs or newcomers to enter, using domestic economic resources, family-owned economic enterprises, small-scale, using laborintensive technology, and technology adapted to the skills needed. needed is not regulated by the government and operates in a fully competitive market (Haryanto, 2016).

The availability of the informal sector to accommodate the workforce occurs because the economic activities carried out are small (marginal) which have the following characteristics: (1) the pattern of activities is irregular, both in terms of time, capital and revenue. (2) it is not touched by regulations or provisions set by the government, (3) the capital for equipment and supplies as well as the turnover is usually small and is managed on a daily basis, (4) generally does not have a permanent place of business and is separated from the place of residence, (5) do not have linkages with other large businesses, (6) are generally carried out by and serve low-income groups of people, (7) do not require special expertise and skills, so that they can absorb various levels of workforce education, (8) In general, each business unit employs a small number of personnel and is in an environment of family relations, acquaintances or from the same area, (9) not familiar with the banking, bookkeeping, credit system and so on (Hartomo, 2008).

The informal sector is often associated with an anticipation of the negative consequences of urban population growth. This population growth tends to show a very fast development, so that the city is always a concentration of the population of a country. therefore it is not surprising that these conditions become an attraction for the surrounding population to come to urban areas (Rohman, 2017). As a result, villagers who are not equipped with sufficient skills and education will do whatever can be used to survive. One of them is by working in the informal sector (Eka Evita, 2019). One of the icons that is being hunted by the public is the terminal. Terminal is a very complex facility, many specific activities are carried out there, sometimes simultaneously. The terminal is not only a major functional component of the 
transportation system but also an infrastructure which is a big cost and a point of congestion that occurs (Morlok, 1995).

The high population causes an imbalance between the demand for labor and the supply of labor in Indonesia. This becomes a problem in improving the economy. To meet the needs of their lives, people do various ways, one of which is to become a street vendor. According to Regional Regulation No. 3 of 2014 concerning the Arrangement and Empowerment of Street Vendors, what is meant by street vendors are business actors who carry out trading business with movable or immovable trading business facilities, using city infrastructure, social facilities, public facilities, land and buildings. owned by the government and/or private sector which is temporary and not permanent. Street vendors are an alternative to businesses in the informal sector with relatively small capital to support their needs. In meeting our daily needs, we certainly need income or income. therefore, we need a job which is to support our needs (Samosir, 2017).

In general, street vendors sell various kinds of merchandise, ranging from food, household utensils and other goods needed by the community. The existence of street vendors can also be a provider of cheap goods and services for low-income residents. Conditions that require small capital and low operating costs make the prices of goods sold by street vendors very cheap (C, 1985).

In general, the motivation of traders is to earn enough income to just survive by working without knowing the time. Street vendors are completely dependent on the income earned on the same day from their sales. But besides that, the implementation of the relocation, where the relocation is one of the government's policies to bring the Terminal in order to make it better.

Relocation in the Indonesian dictionary translated relocation is rebuilding housing, assets, including productive land, and public infrastructure in another location or land. In relocation there are objects and subjects affected in the planning and construction of relocation. Relocation is moving from one place to a new place (Hasnawati, 2016).

Along with that, the condition was exacerbated by the outbreak of the corona virus. Corona virus is a global pandemic that causes concern from various circles, especially the public. People's concerns are increasingly felt seeing the surge in patients who are positive for corona every day. Seeing the spread of this virus, which 


\section{Analysis Of Behavior And Sosio-Economic Impact Of Relocation \\ Of Street Vendors During The Covid-19 Pandemic \\ Sinta Putri Janah dan Hendri Hermawan Adinugraha}

is quite high, requires the government to take strategic steps. A number of policies have been taken, including closing playgrounds, tourist attractions, canceling teaching and learning activities at schools and prohibiting people from gathering (social distancing), PSBB to PPKM (Nadhirah, 2021).

This pandemic has resulted in where previously their economy was able to be fulfilled properly, with this pandemic all sales activities of street vendors experienced a decline, initially selling food sold out but because of this pandemic food sales were not sold out or did not sell at all. Because buyers minimize interacting with their families and the surrounding community, in this pandemic situation it will cause excessive anxiety, always feeling suspicious of someone who is experiencing symptoms such as covid-19 so that income is not as usual, because people don't buy a lot of food that is served directly rather than buying from street vendors (Sutedjo, 2021)

Based on this background, a problem can be formulated regarding how is the behavior of street vendors in the perspective of Islamic Business Ethics, how is the impact of the socio-economic conditions of the relocation of street vendors before and the Covid-19 pandemic with the aim of finding out how behavior of street vendors in the perspective of Islamic Business Ethics, how the socio-economic conditions of the relocation of street vendors before and after the Covid-19 pandemic. Based on the description above, this study only aims as a theoretical on "Analysis of the Behavior and Socio-Economic Impact of Relocation of Street Vendors during the Covid-19 Pandemic"

\section{Literature Review}

\section{Behavior}

According to Purwanto (2015) behavior is all visible or invisible human actions or actions that are based on or not based on it, including how to talk, how to do things and react to everything that comes from outside and from within.

In the Big Indonesian Dictionary, behavior is a response or individual reaction that is manifested in movement (attitude) not only in body or speech. In everyday life, the term behavior is equated with behavior. Behavior has a broad enough meaning so that it includes all statements or expressions that mean not just actions but also words, written expressions and gestures (Devos, 1987). Experts have their 
own views on the meaning of this behavior, here is a list of definitions according to experts in their fields.

According to Moefad, this behavior occurs because there are strong impulses from within a person himself. In trading activities (business), business actors and consumers (users of goods and services) both have needs and interests. Business actors must have responsibilities towards consumers, employees, shareholders, communities and the environment in all aspects of the company's operations. For this reason, it is necessary to have rules and values that regulate these activities, so that no parties are exploited, especially consumers who are in a weak position. As for what needs to be considered in trading is the behavior of traders.

From some of the definitions above, it can be understood that what is meant by trader behavior is a response or reaction of traders to stimuli or the environment around them. Merchant behavior is also a trait that every trader has, to capture the reaction that has been given by the environment to the current situation.

\section{Street Vendors}

Traders are those who carry out commercial activities as their daily work. Commercial acts are generally the act of buying goods for resale. Traders are divided into three namely : (1) Wholesalers/ distributors/ sole agents Distributors are traders who buy or get merchandise from first hand or producers directly. Wholesalers are usually given certain regional/regional authority rights from producers. (2) Middle traders/ agents/ wholesalers. Agents are traders who buy or get their merchandise from a distributor or sole agent who will usually be given a certain sales/trade jurisdiction which is smaller than the distributor's jurisdiction. (3) Retailer/retailer. Retailers are traders who sell goods they sell directly to end users or consumers in units or retail.

Meanwhile, street vendors are one of the urban community groups who usually carry out buying and selling activities in public places. In this regard, the economic activities of street vendors are not only chaotic, but also often do not heed the rules of city planning and public order. As a result, problems arise with traffic barriers and public order, both in big cities and in small towns (Hasmah, 1996).

Street vendors are business actors who carry out trading business using movable or immovable business facilities, using city infrastructure, social facilities, 


\section{Analysis Of Behavior And Sosio-Economic Impact Of Relocation \\ Of Street Vendors During The Covid-19 Pandemic \\ Sinta Putri Janah dan Hendri Hermawan Adinugraha}

public facilities, and government and/or private buildings that are temporary or not permanent.

Street vendors are people who carry out trading or service business activities, namely serving the needs of goods or food that are consumed directly by consumers, who tend to move around with small or limited capital capabilities, in carrying out these businesses using simple equipment and having a location in public places (especially on sidewalks or part of the road), with no formal legality (Yuniarti, 2019).

\section{Islamic Bussines Ethics}

Business Ethics Etymologically (language) ethics comes from the Greek word ethos. In the singular, ethos means the usual place of residence, pasture, stable, habits, customs, morals, feelings, ways of thinking. In the plural, ta etha means custom. In terms of philosophy, ethics means the science of what is usually done or the science of habit. In the Big Indonesian Dictionary, ethics is the science of moral principles.

According to Muslich (2004), business ethics can be interpreted as knowledge of the ideal procedures for business regulation and management that pays attention to norms and morality that are universally applicable and economically/socially, and the determination of these norms and morality supports the aims and objectives of business activities.

(Qardhawi, 1997), in his book Islamic economic norms and ethics has clearly separated values and behavior in trade. Among the sharia norms or values are as follows: (1) Enforce the prohibition of trading prohibited goods. The behavior that arises from understanding this value is the prohibition of circulating illicit goods, either by buying, selling, transferring, or in any way to facilitate their circulation. (2) Be true, trustworthy, and honest. The correct behavior is the spirit of faith, the main characteristic of the believer, even the characteristics of the prophets. Without truth, religion will not be established and will not be stable. On the other hand, lying and lying are part of hypocrisy. The biggest catastrophe in today's market is the widespread use of lies and vanity, such as lying in promoting goods and setting prices. The mandate is to return any rights to their owners, not to take anything beyond their rights and not to reduce the rights of others, either in the form of prices or wages. Honest, in addition to being true and holding a mandate, a trader must be honest, based on the desire that other people get the good and happiness as he wants 
it by explaining the defects of merchandise that he knows and which is not visible to the buyer, (3) Uphold justice and forbid interest. The behavior of this value includes not doing baiy gharar (buying and selling that contains ambiguity), not transacting with usury institutions, perfecting the scales and measurements, not hoarding goods with the aim of playing with prices, hastening to pay debts when the time comes, making records of all business transactions, and pay employee salaries on time, (4) Applying love and prohibiting monopoly. Love is made by Allah as a symbol of the message of Muhammad SAW. Islam wants to enforce under the auspices of market norms. Great humanity respects the small, the strong helps the weak, the stupid learn from the smart, and humans oppose injustice. Therefore, Islam forbids monopoly, an element that applies in capitalist understanding besides usury. What is meant by monopoly is to hold goods from circulation in the market so that their prices rise. Among the behaviors related to this value are not displacing other traders, not monopolizing, and not badmouthing other people's businesses, (5) Uphold tolerance and brotherhood. One of the commendable morals is tolerance and avoiding exploitation factors. The act of exploitation has colored the world of trade, especially trade under the auspices of the capitalists. One of the ethics that must be maintained is to protect the rights of others for the sake of maintaining brotherhood. If individuals in the capitalist system do not heed matters relating to ethics such as ignoring the feelings of others, not knowing morals in the economic field, and only pursuing profit, then on the contrary, Islam is very concerned about it. Islam recommends to traders that they give charity as much as possible to cleanse their association from deceit, perjury and lies, (6) Adhering to the principle that trade is a provision for the hereafter. Provision of Merchants to the Hereafter, one of the morals that should not be forgotten is that, even though a Muslim has made millions of dollars in profits through trade and transactions, he has not forgotten his God. $\mathrm{He}$ did not forget to uphold religious law, especially prayer which is an eternal relationship between humans and their God.

\section{Relocation}

The definition of relocation in the Indonesian dictionary is translated as relocation is rebuilding housing, assets, including productive land, and public infrastructure in another location or land. In relocation, there are objects and subjects affected in the planning and development of relocation (Lestari, 2018). 


\section{Analysis Of Behavior And Sosio-Economic Impact Of Relocation \\ Of Street Vendors During The Covid-19 Pandemic \\ Sinta Putri Janah dan Hendri Hermawan Adinugraha}

In general, the notion of relocation is often interpreted simply as a transfer of place in terms of geographical space. In fact, it cannot be denied that relocation involves the struggle between various concepts of space, such as economic, social, political, environmental and cultural spaces.

The location and quality of the new relocation site is an important factor in relocation planning, because it largely determines things such as ease of access to business land, social networks, employment, business fields, credit and market opportunities. Each location has its own limitations and opportunities. Choosing a location that is similar to the former area in terms of environmental, social, cultural and economic characteristics will make relocation and income recovery more likely to be successful.

\section{Socio-Economic}

Socio-economy is an activity that involves a person in relation to other people in terms of fulfilling the needs of economic life. Socio-economic definitions are rarely discussed together. Social understanding and economic understanding are often discussed separately. Social understanding in social science refers to the object, namely society. Socio-economy is everything related to meeting the needs that exist in the community or more generally related to the welfare of the community. Based on this, people can be classified as upper, middle and lower socioeconomic conditions.

Economic life, namely humans have basic needs that must be met in order to survive. This means that humans have an economic life that requires meeting basic needs both as individuals and as members of society. It is a quadratic for humans from birth to have a problem in the economic field that surrounds their life process because economic problems are a matter of how one can maintain their survival so that it can be said that economic problems cannot be separated from human life.

Rizqyana Budi (2018) explains socio-economic conditions as a link between social status and daily living habits that have become entrenched for individuals or groups where these entrenched living habits are usually called culture activities.

Socio-economic is a concept, and to measure the socio-economic must be through the variables of family income, education level and employment. F.S Chapin (Kaare, 1989) argues that socio-economic is the position placed by individuals or families with respect to the generally accepted average measure of cultural 
ownership, effective income, ownership of goods and participation in group activities of their community.

\section{Methods}

This study uses a descriptive research method with a qualitative approach. Sources of data used are primary data and secondary data. Data collection techniques by observation, interviews, and documentation. The population in this study are street vendors which include food and beverage traders. Data was collected by means of structured interviews with the help of interview and observation guidelines. Structured interviews were conducted to obtain data on the average income for a month before and during the covid-19 pandemic and then whether there were changes in location, selling time, and interaction patterns between traders and buyers. Observations were made to determine which route to use.

The research data was analyzed descriptively to find out whether the behavior of the street vendors was in accordance with sharia business ethics, whether or not there were changes in the amount of capital, income, sales locations, and interaction patterns with buyers during relocation before and during the covid 19 pandemic.

\section{Discussion}

According to Purwanto (2015) behavior is all visible or invisible human actions or actions that are based on or not based on it, including how to talk, how to do things and react to everything that comes from outside and from within. According to Umuri \& Ibrahim (2020) in their journal entitled "Analysis of Street Vendor Behavior According to the Review of Islamic Business Ethics", shows that the behavior of street food vendors in Banda Aceh City is in accordance with Islamic business ethics, such as religious behavior (tawhid), balance ( adl), free will (ikhtiyar), responsibility (fard), and virtue (ihsan).

According to Gustiarni (2015) in his journal entitled Analysis of Islamic Business Ethics on the Behavior of Street Vendors at the Panorama Market in Bengkulu City, it was found that street vendors did not use Islamic business ethics properly in trading. At the time of prayer, the traders still held their wares and did not care about the time of prayer. 


\section{Analysis Of Behavior And Sosio-Economic Impact Of Relocation \\ Of Street Vendors During The Covid-19 Pandemic \\ Sinta Putri Janah dan Hendri Hermawan Adinugraha}

According to Anggraini (2017) in his journal entitled "Analysis of Street Vendor Behavior in the Padang Beach Image Area", that the environment is not wellmaintained in the Padang beach area and traders who sell clothes in the Padang beach area have not implemented a good marketing concept.

Meanwhile, street vendors are one of the urban community groups who usually carry out buying and selling activities in public places. In this regard, the economic activities of street vendors are not only chaotic, but also often do not heed the rules of city planning and public order. As a result, problems arise with traffic barriers and public order, both in big cities and in small towns (Hasmah, 1996).

From the above understanding it can be concluded that street vendors are those who do business in public places without or with permission from the government. These are some of the definitions of street vendors, where street vendors are a type of work in the informal sector that has a non-permanent workplace, and is easily accessible for those who want to do a job but only have limited funds.

The characteristics of street vendors according to (Buchari, 2016) are: (1) Business activities are not well organized, (2)Do not have a business license Irregular in business activities, both in terms of place of business and workplace, (3) Clustered on the sidewalks or on the edges of protocol roads, in crowded centers, (4) Peddling their wares while shouting, sometimes running towards consumers.

While the characteristics of Street Vendors (PKL) according to Agus (2017) include; (1) Business activities are not well organized, (2) Most street vendors do not have a business license, (3) If you look at it from the point of view of time and place, it seems as if the street vendors are not organized, (4) They carry out activities always by approaching their consumers.

In general, the notion of relocation is often interpreted simply as a transfer of place in terms of geographical space. In fact, it cannot be denied that relocation involves the struggle between various concepts of space, such as economic, social, political, environmental and cultural spaces.

The location and quality of the new relocation site is an important factor in relocation planning, because it largely determines things such as ease of access to business land, social networks, employment, business fields, credit and market opportunities. Each location has its own limitations and opportunities. Choosing a location that is similar to the former area in terms of environmental, social, cultural 
and economic characteristics will make relocation and income recovery more likely to be successful.

According to Pasciana et al. (2019) in their journal entitled "Relocation of Street Vendors (PKL) to Beautify Garut City", it shows that the evaluation of the PKL relocation program policy in Garut Kota has not achieved optimal results. The number of street vendors who returned to the red zone and did not want to be relocated made the street vendors building abandoned. Based on the research results, the Garut Regency Government is expected to carry out regular coaching and empowerment, hold a discussion forum between street vendors and the Garut Regency Government to find joint solutions, and the relocation building should be immediately taken over by the Regent so that it can be utilized and managed better

Socio-economic conditions are a socially regulated position and place a person in a certain position in society, the granting of that position is accompanied by a set of rights and obligations that must be played by the status bearer

According to Junaidi et al. (2019) in their journal entitled "The Impact of Market Relocation on Socio-Economic Conditions of Traders at Tente Market, Woha District, Bima Regency" shows that, there is a social change, where technically traders and trading locations from the old market move to the new market. In this market movement, there are impacts, namely social and economic impacts such as manifestations, with the impact of manifestations, there will be impacts behind them, namely, the impact of latency experienced by traders after market relocation. And the lack of intense interaction between old and new traders. The social impacts that arise are changing social systems, lacking personal interactions and relationships. The economic impact that appears is about the declining income after occupying the new Tente market.

According to Sutedjo (2021) in his journal entitled "The Impact of the Covid-19 Pandemic on the Socio-Economic Condition of Mobile Merchants in Kedurus Village, Surabaya City" stated that the capital and income of mobile traders in Kedurus Village during the pandemic decreased compared to before the pandemic because they were not motivated to increase productivity. The interaction of traveling merchants with buyers has not changed and they do not anticipate to deal with changing situations that occur. Hours of work, length of work and location and travel routes have not changed so that it cannot maintain the number of buyers. 


\section{Analysis Of Behavior And Sosio-Economic Impact Of Relocation \\ Of Street Vendors During The Covid-19 Pandemic \\ Sinta Putri Janah dan Hendri Hermawan Adinugraha}

According to Prasetya \& Fauziah (2021) in their journal entitled SocioEconomic Impact of Relocation of Foot Lika Traders in Buduran District, Sidoarjo Regency, it shows that the process of relocating street vendors is not in accordance with the relocation stages as stipulated in Domestic Regulation No. 41 of 2012 which starts from the data collection stage with twice surveys and registration of street vendors, determining the location of street vendors, moving and removing street vendors' locations, to rejuvenating street vendors' locations. The relocation was finally carried out by the Sanitation and Parks Office of Sidoarjo Regency which took discretionary steps over the policy. The social impact of relocating street vendors in the overpass area of Buduran District, in terms of convenience, street vendors feel more comfortable. But in terms of security is still not fully awake. The income of the majority of street vendors has decreased due to the absence of empowerment from the government. The government also has problems relocating street vendors because of the limited land available and the mindset of street vendors who are still comfortable selling on the roadside because there is no place to rent.

According to Mutia (2017) in his journal entitled "Evaluation of the impact of the relocation policy of Street Vendors (PKL) in Pasar Minggu, South Jakarta" shows that, the impacts caused by the relocation carried out by the government are: 1) social impacts that occur on traders, there are slow changes as well as fast changes and 2) the economic impact in terms of the income of traders after being relocated there are positive and negative impacts from the relocation.

Then the research according to Wijaya (2017) entitled "The Impact of Covid-19 on the Socio-Economic Condition of Traders in the Klayar Coastal Area, Donorojo District, Pacitan Regency" explains that, the characteristics of socio-economic conditions are based on age, education level, income and expenditure. The positive social impacts felt by traders due to Covid-19 are the return of traditions in society that are almost extinct, having more time with family, the emergence of a sense of mutual cooperation, and the negative impact is unemployment. While the positive impact from the economic point of view is non-existent and the negative impact on income is decreasing. The trader's strategy in dealing with the Covid-19 problem is to do side or temporary work for the sake of living while not trading. 


\section{Conclusion}

Based on the results of research and discussion that the behavior of street vendors in buying and selling transactions on average is in accordance with Islamic business ethics, as manifested by traders by praying on time, not selling dangerous (haram) food, prioritizing buyers according to queues and setting prices that are right. the same for all buyers, being honest with buyers, always fulfilling buyers' orders, friendly and serving buyers, maintaining good relations with buyers and fellow traders.

Another socio-economic impact of relocating street vendors during the Covid19 pandemic is that the income of street vendors during the Covid-19 pandemic has decreased compared to before the pandemic. Factors that affect the decline in income such as the number of buyers and customers are reduced, the amount of capital used is small and reduced so that the merchandise sold is reduced. Then the factors that cause street vendors to maintain their business during the Covid-19 pandemic include the necessities of life, low education, inadequate skills, ease of entering the informal sector and having small capital.

\section{Reference}

Anggraini, D. (2017). Analisis Prilaku Pedagang Kaki Lima Terhadap Kawasan Citra Pantai Padang. Jurnal Menara Ilmu, XI(77), 18-24.

C, E. T. (1985). Urbanisasi Pengangguran dan Sektor Informal di Kota Usman. Jakarta: Penerjemah: Jakarta (ID).

Devos. (1987). Pengantar Etika. Yogyakarta: Tiara Wacana.

Eka Evita, d. (2019). Implementasi Kebijakan Penataan Pedagang Kaki Lima (Studi pada Batu Tourism Center kota Batu). Jurnal Administrasi Publik.

Gustiarni, Y. (2015). Analisis Etika Bisnis Islam Terhadap Perilaku Pedagang Kaki Lima Di Pasar Panorama Kota Bengkulu.

Hasnawati. (2016). Dampak Relokasi Pasar terhadap Pedagang Pasar Laino raha. Skripsi.

Hidayat, M. R., \& Rahmaniah, A. (2015). Perilaku Pedagang Di Pasar Tradisional Sentra Antasari Banjarmasin Dalam Perspektif Etika Bisnis Islam. Turfgrass, 32, 589-614. https://doi.org/10.2134/agronmonogr32.c17

Junaidi, M., Ramayanto, R., \& Nurlailatul, N. (2019). Dampak Relokasi Pasar 


\section{Analysis Of Behavior And Sosio-Economic Impact Of Relocation \\ Of Street Vendors During The Covid-19 Pandemic \\ Sinta Putri Janah dan Hendri Hermawan Adinugraha}

Terhadap Kondisi Sosial Ekonomi Pedagang Pasar Tente Kecamatan Woha Kabupaten Bima. JIAP (Jurnal Ilmu Administrasi Publik), 6(1), 1. https://doi.org/10.31764/jiap.v6i1.659

Karuniawan, M. H., \& Sukma, A. P. (n.d.). Analisis Dampak Sosial Ekonomi Relokasi Pedagang Kaki Lima (PKL) (Studi PKL di Gelanggang Olah Raga (GOR) Kabupaten Sidoarjo). 107-116.

Lestari, L. P. (2018). Analisis Dampak Sosial Ekonomi Relokasi Pedagang Kaki Lima ( Studi Kasus Pedagang Kaki Lima Eks Kebondalem Di Pasar Sarimulyo Purwokerto ).

Mutia, M. K. (2017). Evaluasi Dampak Kebijakan Relokasi Pedagang Kaki Lima (PKL) di Pasar Minggu, Jakarta Selatan. Universitas Katolik Parahyangan, 3841. http://repository.unpar.ac.id/bitstream/handle/123456789/2025/Cover Bab 1 - 3111061sc-p.pdf?sequence=1\&isAllowed=y

Mulyadi. (2003). Ekonomi Sumber Daya Manusia dalam Perspektif Pembangunan. Jakarta: PT.Raja Grafindo Persada.

Muslich. (2004). Etika Bisnis Islam. Yogyakarta: Ekonesia.

Morlok. (1995). Pengantar Teknik dan Perencanaan Transportasi . Jakarta: Erlangga.

Nadhirah, S. M. (2021). Kondisi sosial ekonomi di masa pandemi pada pedagang kaki lima di kelurahan bantan kecamatan medan tembung skripsi.

Pasciana, R., Pundenswari, P., \& Sadrina, G. (2019). Relokasi Pedagang Kaki Lima (Pkl) Untuk Memperindah Kota Garut. Kolaborasi : Jurnal Administrasi Publik, 5(3), 288-303. https://doi.org/10.26618/kjap.v5i3.2649

Prasetya, M. A., \& Fauziah, L. (2021). Dampak Sosial Ekonomi Relokasi Pedagang Kaki Lima di Kecamatan Buduran Kabupaten Sidoarjo. JKMP (Jurnal Kebijakan Dan Manajemen Publik), 4(2), 135-150. https://doi.org/10.21070/jkmp.v4i2.691

Qardhawi, Y. (1997). Norma dan Etika Ekonomi Islam. Jakarta: Gema Insani Press.

Samosir, R. A. (2017). Skripsi: Analisis Pendapatan Pedagang Kaki Lima Sektor Informal Kec.Semarang. Fakultas Ekonomi dan Bisnis, Universitas Diponegoro.

Sutedjo, A. (2021). Dampak Pandemi Covid-19 Terhadap Kondisi Sosial Ekonomi Pedagang Keliling Di Kelurahan Kedurus Kota Surabaya. JURNAL GEOGRAFI $\begin{array}{llll}\text { Geografi Dan } & \text { Pengajarannya, }\end{array}$ https://doi.org/10.26740/jggp.v19n1.p25-34

Umuri, K., \& Ibrahim, A. (2020). Analisis Perilaku Pedagang Kaki Lima Menurut Tinjauan Etika Bisnis Islam. 6, 187-197. 
Wijaya, A. S. (2017). Dampak Covid-19 Terhadap Kondisi Sosial Ekonomi Pedagang Di Kawasan Pantai Klayar Kecamatan Donorojo Kabupaten Pacitan Tahun 2020. 1-20.

Yuniarti, P. (2019). Analisis Faktor-Faktor Yang Mempengaruhi Pendapatan Pedagang Di Pasar Tradisional Cinere Depok. Widya Cipta - Jurnal Sekretari Dan Manajemen, 3(1), 165-170. https://doi.org/10.31294/widyacipta.v3i1.5296 